\title{
MAPAS EM MOVIMENTO: OS (DES)CAMINHOS DE UMA PRÁTICA CARTOGRÁFICA JUNTO AOS POTIGUARA
}

THIAGO MOTA CARDOSO ${ }^{1}$

$U F B A$

LILIAN BULBARELLI PARRA ${ }^{2}$

UFSC

ISABEL FRÓES MORDECIN ${ }^{3}$

$U F B A$

\begin{abstract}
RESUMO: Realizar uma etnografia dos mapas por meio de uma reflexão crítica sobre um processo de etnomapeamento realizado junto ao povo Potiguara $(P B)$ configura o objetivo principal do presente artigo. Tal iniciativa foi proposta pela Fundação Nacional do Índio (Funai) como forma de identificar e descrever conflitos envolvendo a prática da carcinicultura e do cultivo de cana-de-açúcar, bem como a sobreposição entre uma unidade de conservação, terras e territórios indígenas em questão. Ao nos inscrevermos no processo, buscamos construir espaços relacionais calcados na etnografia e em técnicas de mapeamento participativo mescladas ao uso de geotecnologias. Argumentamos que os mapas, mesmo não correspondendo às formas de mapeamento dos povos indígenas, podem, quando construídos com respeito e simetria em relação às práticas inseridas nos sistemas de conhecimento do outro, configurar poderosas estratégias para o diálogo intercultural, em geral assimétrico. Apontamos também para o fato de que, assim como outros mapas produzidos na região, o processo do etnomapeamento foi reorientado pelos Potiguara, para fins, principalmente, de luta territorial - um processo de "cartografofagia", em que as técnicas planejadas de "cima", isto é, pelo órgão indigenista, foram digeridas e tratadas como "mapas indígenas".
\end{abstract}

PALAVRAS-CHAVE: Potiguara; etnomapeamento; território.

ABSTRACT: The objective of this article is to perform an ethnography of maps through a critical reflection on an ethnomapping process realized with the Potiguara indigenous people. The ethnomapping in the Potiguara lands was proposed by Funai as a way of identifying and describing conflicts involving the practice of shrimp farming and sugarcane plantation, as well as the overlap between conservation reserves and the indigenous territory. Our objective was to build relational spaces based on ethnography and participatory mapping techniques, combined

${ }^{1}$ Biólogo, Mestre em Ecologia e Doutor em Antropologia Social pela Universidade Federal de Santa Catarina (UFSC), Pós-Doutorando no Programa de Pós-Graduação em Antropologia da Universidade Federal da Bahia (UFBA). E-mail: thiagotxai@gmail.com.

${ }^{2}$ Mestre em Geografia pela Universidade Federal de Santa Catarina (UFSC). Pesquisadora do Wayuri Assessoria e Projetos socioambientais. E-mail: lilianbparra@gmail.com.

${ }^{3}$ Bióloga e Mestre em Antropologia pela Universidade Federal da Bahia (UFBA). Pesquisadora do Wayuri Assessoria e Projetos socioambientais. E-mail: imodercin@gmail.com. 
with the use of geotechnologies. We argue that maps, even if they do not correspond to the forms of mapping of many indigenous peoples, if constructed in a way that respects the symmetries between practices of knowledge, are powerful instruments for intercultural dialogue, which is usually asymmetrical. We have observed, first of all, that, like other maps produced in the region, the process of ethnomapping was reoriented by the Potiguara people as a weapon for territorial demand - a process of "cartographophagy", where the cartography tecnoscience were absorved and treated as "indigenous maps".

KEYWORDS: Potiguara; ethnomapping; territory.

\section{Introdução}

Em 2010, formamos uma equipe interdisciplinar e um coletivo indígena a fim de iniciarmos um processo de etnomapeamento do território junto ao povo Potiguara, grupo tupi que habita três Terras Indígenas (Potiguara, Potiguara de Monte Mór e Jacaré de São Domingos) no litoral norte da Paraíba. Este estudo, publicado recentemente (CARDOSO et al, 2012), ocorreu por meio de um projeto no âmbito de um convênio entre a Fundação Nacional do Índio (Funai) e a Organização das Nações Unidas para a Educação, Ciência e Cultura (Unesco) ${ }^{4}$, corroborando com a proposta de fomento à gestão territorial em terras indígenas, conforme o debate em voga no período, que culmina nos anos 2012 com a homologação da Política Nacional de Gestão Ambiental em Terras Indígenas - PNGATI (BRASIL, 2012).

Entre os objetivos de tal iniciativa junto aos Potiguara, estiveram a identificação e a descrição dos conflitos envolvendo a prática da carcinicultura, o plantio de cana-de-açúcar e a sobreposição de terras e territórios indígenas com unidades de conservação (CARDOSO et al, 2012). Ao nos engajarmos em tal experiência cartográfica sobre os territórios Potiguara, objetivamos transpor o enfoque dado aos conflitos ambientais e voltar-nos à construção de espaços relacionais calcados no diálogo de saberes no qual acionamos, dentre as estratégias, etnografias e técnicas de mapeamento participativo mescladas ao uso de

\footnotetext{
${ }^{4}$ Em termos institucionais o etnomapeamento foi promovido pela Coordenação Geral de Monitoramento Territorial da Fundação Nacional do Índio - CGMT-FUNAI, via cooperação técnica com UNESCO, no qual fomos consultores.
} 
geotecnologias.

O presente artigo visa realizar uma descrição etnográfica de práticas cartográficas que permearam o referido mapeamento junto aos Potiguara. Nosso intento mais amplo neste artigo é o de "repensar os mapas" (KITCHIN e DODGE, 2007), explicitando, por meio de uma antropologia da cartografia (WOOD, 2012; POSTIGO, 201 0; SLETTO, 2009; TURNBULL, 2003), os caminhos, as práticas e as controvérsias do processo de etnomapeamento de territórios indígenas que, como bem propõe Almeida (2012), é composto por diversas cartopráticas. Nos dedicamos a refletir criticamente sobre as descontinuidades e os desdobramentos do etnomapeamento.

No caminhar do presente artigo, notamos primeiramente que, assim como outros mapas produzidos na região ao longo da história do contato interétnico, o processo do etnomapeamento foi reorientado pelos Potiguara, num processo de "cartografofagia"5, em que as técnicas planejadas de "cima" - isto é, pelo órgão indigenista - foram "digeridas" e tratadas como "mapas indígenas" para fins, principalmente, de luta territorial6, num processo cosmopolítico em que nenhuma parte envolvida detinha o controle da narrativa. Em segundo lugar, tal processo etnográfico e cartoprático que fazemos sobre o mapeamento foi proporcionado pelo nosso engajamento na experiência e abriu a possibilidade à construção de uma crítica sobre o ato de mapear, tido na maioria das vezes como o modo de se representar um território ao mesmo tempo em que concretiza fronteiras (TURNBULL, 2003). Nesse sentido, argumentamos que a tecnociência do fazer mapas está imersa em assembleias sociotécnicas que entrelaçam diferentes coletivos de pessoas, coisas e seres em seus projetos de mundo e modos de viver, de forma a fazer parte do ato de co-delinear territórios, e não apenas evidenciá-los.

\section{Etnomapeamento e povos indígenas}

\footnotetext{
5 Neologismo, ou uma licença poética, associado ao prefixo antro (antropos $=$ humano) e o termo fagia (comer, devorar), para conceber metaforicamente a captura ou incorporação dos mapas pelos Potiguara.

${ }^{6}$ É importante frisar que não pretendemos tratar da territorialidade Potiguara ou dos processos territoriais do Estado brasileiro, devido o curto espaço deste artigo. Este tema já foi tratado por diversos outros autores como Vieira (2010), Liedke (2009), Palitot (2005), Peres (2000), Silva (1993), e Azevedo (1986).
} 
Do ponto de vista da política indigenista e ambiental, os etnomapeamentos, bem como os etnozoneamentos, são considerados ferramentas centrais no ciclo de gestão territorial e ambiental de Terras Indígenas (LITTLE, 2006). Ocorrem com a prerrogativa de serem interculturais e intercientíficos: técnicos e indígenas buscam também produzir mapas através de bases cartográficas sofisticadas, recheadas de atributos e categorias classificatórias advindas dos conhecimentos indígenas. No âmbito da Política Nacional de Gestão Territorial e Ambiental de Terras Indígenas (PNGATI), os etnomapeamentos possuem lugar privilegiado, sendo definidos como o "mapeamento participativo das áreas de relevância ambiental, sociocultural e produtiva para os povos indígenas, com base nos conhecimentos e saberes indígenas" (BRASIL, 2012). Em nota técnica de 2013, a Funai emitiu a seguinte definição de etnomapeamento: "Ferramenta de diagnóstico que consiste nas formas de representação espacial do território de acordo com a classificação indígena do espaço e de seus elementos característicos".

A gestão territorial, como vem sendo tratada formalmente desde os anos 90 nos processos de etnomapeamento, etnozoneamento e planos de gestão territorial (CORREIA, 2007; GAVAZZI, 2008; TRANCOSO et al, 2012), bem como em diversas políticas públicas junto aos povos indígenas (MILLER, 2008; VERDUM, 2006), tem por base a modalidade de territorialização estatal, a Terra Indígena, e não necessariamente a territorialidade dos diversos povos e comunidades. Não nos espanta que seus "instrumentos" sejam similares àqueles acionados para 0 ordenamento territorial estatal.

A visão de um território como espaço de gestão, com foco na Terra Indígena, abarca apenas um aspecto parcial da riqueza conceitual da visão territorial desenvolvida no cotidiano indígena (HIERRO, 2004; GALLOIS, 2004). Aqui, é necessário distinguir entre um conceito de terra como um lugar em que se vive e o de território como um esquema jurídico-político ancorado fundamentalmente em fronteiras geográficas para pensarmos - de forma contrastante e articuladora - as dimensões sociopolíticas e cosmológicas mais amplas dos povos indígenas (SEEGER e VIVEIROS DE CASTRO, 1978). Não menos importante é reconhecer a complexidade inerente à percepção e à concepção de território indígena 
de cada povo, já que a noção de Terra Indígena ( $\mathrm{Tl}$ ) corresponderia a uma categoria de território vinculada à administração estatal, enquanto os territórios indígenas transcendem essas fronteiras ontológicas (GALLOIS, 2004; HAESBAERT, 2004; VIEIRA, AMOROSO e VIEGAS, 2015; SURRALES e GARCÍA HIERRO, 2005). As concepções de território dos povos indígenas podem vir a encontrar eco não somente na materialidade dos limites geometricamente definidos, mas nas relações calcadas nas experiências, nas cosmologias e nos elos ancestrais estabelecidos em conexões com outros seres humanos e não humanos.

De fato, a noção de gestão territorial das Terras Indígenas desponta, ou torna-se visível, pela emergência dos movimentos indígenas e pela proliferação de associações em diversas escalas, com a transformação da política indigenista e a superação do "funil demarcatório", o que nos leva à noção de que a realidade das terras tradicionalmente ocupadas oscila entre a demarcação e o controle e manejo dos territórios. Outros fatores que contribuem para esse despontar são a percepção crescente da interdependência entre a biodiversidade e a sociodiversidade e o debate sobre a sobreposição entre Tls e Unidades de Conservação (UC) da natureza (BARRETO-FILHO e CORREIA, 2009).

Segundo Barreto-Filho e Correia (2009), as experiências interculturais e, diríamos também, intercientíficas de gestão ambiental e territorial das Terras Indígenas emergem no Brasil como uma "questão socialmente construída", principalmente na segunda metade da década de 1980, enquanto preocupações dos indigenistas e ambientalistas com os temas da autonomia e da sustentabilidade, notadamente entre os povos da Amazônia. No Nordeste, onde a preocupação se concentrou nos processos identitários e territoriais, as temáticas ambientais associadas à gestão dos territórios têm se manifestado de forma ainda tímida. Podemos afirmar que, mesmo diante de algumas experiências de diagnósticos etnoambientais realizados no Nordeste, a experiência de gestão territorial intercultural dos Pataxó, do extremo sul da Bahia, e dos Potiguara se constituem como pioneiras na região por seu caráter endógeno, dialógico e processual.

Segundo Little (2006), as atuais formas de gestão territorial e ambiental realizadas através do diálogo intercultural surgem à medida 
que grupos étnicos levantam reivindicações frente ao Estado. Durante as décadas de 1980 e 1990, os movimentos etnopolíticos dos povos indígenas estavam voltados ao reconhecimento formal por parte do governo federal de seus territórios, mediante criação das Terras Indígenas ${ }^{7}$. Em anos mais recentes, esses movimentos começaram a se transformar em associações, formadas em moldes ocidentais, para captar recursos financeiros mediante a elaboração e implementação de projetos de "desenvolvimento sustentável". Portanto, no campo da gestão territorial de Terras Indígenas, há duas grandes agendas políticas que atuam e se interrelacionam: a agenda de direitos étnicos e territoriais dos povos indígenas e a agenda ambientalista da sustentabilidade.

Etnomapeamentos são vistos nessa seara como instrumentos de planejamento de gestão, ou seja, como parte de uma gama de instrumentos de diagnóstico e planejamento territorial utilizados de forma experimental em territórios e terras indígenas. Em geral, eles (mapeamentos, diagnósticos rurais, zoneamentos, planos) são utilizados, segundo Smith e Guimarães (2010), para uma melhor compreensão da dinâmica sociocultural de uso dos espaços e dos recursos, tanto interna como externa às terras indígenas, e para a formulação de estratégias de gestão, que servem para orientar as ações dentro dos territórios. Contudo, também almejam subsidiar a resolução de conflitos socioambientais, orientar as ações dos povos indígenas com base nas noções de preservação e conservação ambiental, promover o manejo dos recursos naturais, fortalecer a identidade e a autonomia indígenas e, ainda, estimular o diálogo entre lideranças indígenas e representantes de instituições governamentais e não-governamentais, entre outros (CORREIA, 2007).

Por privilegiar as formas eurocêntricas de conhecimento e de gestão, com foco na instituição de sistemas estatais de propriedade da terra, as iniciativas de gestão empreendidas pelas agências indigenistas e ambientalistas do poder público, por ONGs e agências multilaterais, constantemente se munem de recursos da cartografia e das geotecnologias nos etnomapeamentos (LITTLE, 2006; SMITH e

\footnotetext{
${ }^{7}$ No tocante à noção de terras indígenas, a Constituição Federal estabelece o seguinte: "Art. 231. São reconhecidos aos índios sua organização social, costumes, línguas, crenças e tradições, e os direitos originários sobre as terras que tradicionalmente ocupam, competindo à União demarcá-las, proteger e fazer respeitar todos os seus bens".
} 
GUIMARÃES, 2010). O que se deve ao fato de partirem do pressuposto de que a cartografia técnico-científica é uma ciência supostamente capaz de dar voz e "precisão" ao ordenamento territorial do Estado brasileiro; assim, os etnomapas se apresentam, conforme definidos na PNGATI, como uma variação dentro da prática cartográfica que busca dar continuidade a essa ação estatal por outros meios.

Os etnomapas podem servir para potencializar a luta pelo território frente a um Estado que só compreende o território através do olhar representacional e com pressupostos realistas da proliferação de fronteiras e objetos estáveis. Ao mesmo tempo, podem servir para melhorar a qualidade do diálogo entre a política indigenista e ambientalista, bem como para subsidiar a negociação entre projetos indígenas, projetos de ONGs e empreendimentos econômicos. Podem, ainda, vir a evidenciar formas diferentes de manejar determinados recursos; entre caminhos, interpretações e múltiplos interesses, novas possibilidades podem emergir. Os etnomapas podem, em distintos contextos, ser "indigenizados" ou "predados" para fins políticos, o que é legítimo enquanto parte do caminhar pragmático dessas experiências (CARDOSO, 2014).

Há, contudo, diferenças entre os etnomapeamentos e as práticas cartográficas convencionais, sobretudo porque os primeiros buscam incluir ou se aproximar dos múltiplos modos de habitar e conhecer o mundo dos povos indígenas e suas consequentes formas de territorialização, mesmo que, muitas vezes, não deem conta da multiplicidade de modos de geografar em jogo (CARDOSO, 2014; PARRA, 2016; SURRALES e GARCÍA HIERRO, 2005). Da mesma forma, não contemplam a multiplicidade de formas de mapear e fazer o mundo.

Portanto, da mesma forma que a concepção de território nos moldes estatais não contempla a totalidade dos territórios indígenas, os mapas e mapeamentos que vem a atender essa demanda específica abarcam parcialmente a diversidade de territórios vivenciados e construídos pelos povos indígenas. Nesse sentido, faz-se necessário acionar a perspectiva cartográfica mais ampla acerca dos mapas e mapeamentos para dar conta dessa diversidade (PARRA, 2016).

Cardoso (2014) propõe pensar o etnomapeamento como um ato intercientífico e cosmopolítico. O etnomapeamento, assim, não é visto 
apenas, de um lado, como uma intervenção "fina" do Estado nos territórios dos povos indígenas, mas também, de outro, como uma forma de "desideologizar" os mapas oficiais através da agência política dos povos indígenas e de seus conhecimentos (ver ACSELRAD, 2008), entre agencialidades humanas e não humanas em relação muitas vezes assimétrica. Isso exige assumirmos, segundo Cardoso (2014), que, no etnomapeamento, ou em qualquer ato cartográfico, um mapa não é uma representação de um território já dado de antemão, mas o resultado de movimentos no terreno e conversações imersas em um campo de relações de poder. Portanto, o etnomapeamento pode ser visto como um processo vivo, rizomático, no qual os atores (ou organismos) envolvidos se engajam perceptiva, performativa e dinamicamente no mundo, habitando-o num emaranhando de relações, de onde partem narrativas e histórias de lugares e relações, bem como fluxos de poder, mútuo entendimento, acordos, negociações e conexões parciais entre conhecimentos distintos sobre o mundo e sobre o ato de mapear (CARDOSO, 2014, p. 3).

Etnomapas são produtos de um diálogo de verdades parciais (do técnico, do geógrafo, do antropólogo, do indigenista e dos indígenas) utilizados para múltiplos fins: os mapas, enquanto actantes, caminham por caminhos não previstos, acionando contextos na malha relacional. Se nos pautarmos em apontamentos da cartografia contemporânea, temos que, a cada reencontro com os mapas, ocorrem novos mapeamentos olhar, refletir, analisar, completar, rabiscar, rasgar, dobrar, refazer, etc. Os mapas em si, bem como os processos de onde emergem, são permeados por práticas tão diversas quanto os interesses que as movem. Nessa perspectiva, mapas são processuais, pertencem a um continuum - são sempre mapeamentos (DEL CASSINO e HANNAH, 2005, KITCHIN e DODGE, 2007), compostos por uma constelação de práticas. Em concordância com o feliz neologismo de Almeida (2012), são permeados por distintas cartopráticas, inscritas em distintas matrizes do conhecimento.

Ao longo da jornada de um mapeamento, podem ocorrer equívocos e mudanças, numa verdadeira política do habitar (INGOLD, 2005) - ou seja, no encontro e no confronto de formas distintas de se engajar no mundo e de conhecê-lo. Mas, mesmo com equívocos e mal-entendidos 
epistemológicos, ontológicos e práticos, os etnomapas seguem seus caminhos: são como vidas em movimentos. Nossas atenções, aqui, voltam-se para o processo do qual emergem os etnomapas Potiguara, para um fragmento da sua história, e esse repensar se inscreve no continuum do mapeamento.

\section{Potiguara, ambientes e territórios}

Os Potiguara fazem parte dos povos da família linguística tupi e, como todos os povos que vivem no Nordeste, possuem uma longa história de contato com a sociedade não indígena. Segundo dados de 2011 da Funai (CARDOSO et al, 2012), totalizam uma população de aproximadamente 15 mil índios, habitando cerca de trinta e duas aldeias, situadas nas três Terras Indígenas localizadas nas cidades de Baía da Traição, Marcação e Rio Tinto. Um número não contabilizado de índios vive, ainda, em outras cidades, como Mamanguape, João Pessoa e até mesmo no Rio de Janeiro ou no Rio Grande do Norte (PALITOT, 2005). Os Potiguara concentram-se numa área do litoral norte paraibano situada entre os rios Camaratuba e Mamanguape. As três Terras Indígenas contíguas - TI Potiguara, TI Jacaré de São Domingos e TI Potiguara de Monte Mór - perfazem um total de 33.757 ha. E, em 2005, iniciou-se o processo de identificação de outra área denominada Mundo Novo/Viração (VIEIRA, 2010).

$O$ estudo em questão evidenciou serem os territórios Potiguara, considerando-se inicialmente as três Terras, formados por um mosaico paisagístico onde predominam ambientes intensamente manejados, como canaviais, capoeiras finas, carrascos, quintais e sítios ao redor das casas (pomares), com a presença de fragmentos da Mata Atlântica entre Tabuleiros, Manguezais e Restingas. As famílias indígenas, nesse contexto, sobrevivem principalmente de práticas como a agricultura (plantam milho, feijão, mandioca, macaxeira, inhame), a fruticultura e a horticultura; o extrativismo e a coleta vegetal (de mangaba, dendê, caju e madeira, utilizada para construção de casas, embarcações e cercas e para a produção de carvão); o plantio comercial de cana-de-açúcar (geralmente em terras arrendadas para usinas); a pecuária em pequena escala e a criação de outros animais nos sítios e quintais; a pesca marítima 
(sobretudo nas aldeias costeiras, nos rios Mamanguape e Camaratuba e nos mangues), bem como a mariscagem e a carcinicultura. Também trabalham como mão-de-obra rural (principalmente nas usinas de cana) e urbana; alguns são funcionários públicos, e outros contam com a aposentadoria dos idosos da casa para complementar a renda da família.

O povo indígena Potiguara possui uma longa história de luta pela terra. Durante esse período, relações ambientais foram precarizadas, principalmente pela atividade madeireira e pelo avanço do plantio da cana-de-açúcar na região; ao mesmo tempo, a mão-de-obra indígena foi utilizada nesses "empreendimentos", responsáveis pela deterioração da qualidade de vida da população local. A necessidade de discutir alguns conflitos socioambientais na busca por soluções e acordos foi um dos principais motivadores da realização do etnomapeamento enquanto ferramenta capaz de gerar encontros, reflexões e debates sobre determinadas situações relacionadas à gestão ambiental e territorial.

A plantação da cana-de-açúcar pode ser considerada o maior fator de degradação da qualidade de vida humana e não humana no território potiguara, seja pelas alterações nas relações sociais entre os membros do grupo, seja pelos seus impactos no meio-ambiente. Para a implantação da atividade, grandes áreas são desmatadas; os solos, erodidos e contaminados, e os rios, assoreados e poluídos pelo uso de defensivos e adubos químicos. $O$ fogo ateado aos canaviais, além de ocasionar a perda de nutrientes do solo, constantemente avança sobre fragmentos de mata vizinhos, muitos dos quais abrigam nascentes e cursos d'água que secam como consequência (CARDOSO et al, 2012). Além disso, as usinas lançam vinhoto nos rios Mamanguape e Camaratuba, ampliando a mortandade de peixes e crustáceos. A ação das usinas também é dilacerante das relações entre humanos e entre estes e os outros animais não humanos que habitam a região, pois os Potiguara abandonam a prática da pesca, da agricultura tradicional e da coleta para entregarem-se aos trabalhos insalubres oferecidos pelas usinas no corte e na queima de cana.

As sobreposições da Área de Proteção Ambiental (APA) da Barra do Mamanguape e da Área de Relevante Interesse Ecológico (ARIE) da Foz do Mamanguape com as TIs Potiguara e Potiguara de Monte Mór também proporcionam uma série de conflitos socioambientais e territoriais. De acordo com informações do ISA (2013), ocorre sobreposição em 405 
hectares, o equivalente a $2 \%$ da área da TI Potiguara, com a ARIE da Foz do Mamanguape. A TI Potiguara de Monte Mor sobrepõe-se à APA do Mamanguape. Outras Unidades de Conservação fazem fronteira com as terras indígenas, como a Reserva Ecológica (ResEc) Mata do Rio Vermelho, criada em 1984, e a Reserva Biológica (ReBio) Guaribas, de 1990.

Sem entrar no mérito dos impactos positivos ou negativos destas sobreposições, observou-se durante o estudo que tais conflitos se devem ao fato de que a criação destas categorias de Unidade de Conservação implica a imposição de restrições que afetam as relações dos Potiguara com ambientes essenciais para a manutenção de suas práticas, nas áreas sobrepostas ao território indígena. Os Potiguara muitas vezes possuem formas distintas e inversas, quando comparadas as formas técnicocientíficas, de perceber e de se relacionar com outros seres e com a terra, bem como diferentes objetivos de destinação dos espaços vividos (CARDOSO e MODERCIN, 2012).

Dentre os conflitos existentes entre o órgão ambiental fiscalizador e os Potiguara, Cardoso e colaboradores (2012) relatam que o principal destes se refere à existência de tanques de carcinicultura que não se adéquam às exigências da legislação ambiental e que, assim, promovem a precarização de modos de vida, bem como restrições de acesso às áreas de pesca pelos pescadores. A partir de meados da década de 1990, com o incentivo de empresas privadas que investem na carcinicultura no litoral do Nordeste brasileiro, algumas famílias Potiguara construíram tanques para a produção de camarão sobre áreas de manguezais na foz do rio Mamanguape. Essa forma de habitar a terra, apesar de sanar as necessidades econômicas básicas de algumas famílias, gera a destruição de manguezais e apicuns, a poluição hídrica, a modificação do fluxo das marés, a redução e extinção de habitats de numerosas espécies, o aumento de riscos ambientais pela introdução de uma nova espécie de camarão (Litopenaeus vannamei) no manguezal e a difusão de epidemias. Além da degradação dos ambientes, a implantação dos tanques causa impactos econômicos e sociais na medida em que ocasiona a desestruturação das comunidades de pescadores ao diminuir as áreas de trabalho (mariscagem, pesca e captura de caranguejos), restringir o acesso do grupo aos locais de pesca e intensificar conflitos entre os usuários do rio. 


\section{Os mapas no mundo Potiguara}

Mapas não são novidades no mundo dos Potiguara: são conhecidos desde os tempos coloniais, quando foi iniciado o processo de fracionamento dos territórios dos povos indígenas no Nordeste. Desde então, os mapas produzidos pelos "outros" foram usados para legitimar o confinamento dos Potiguara e distribuir terras à elite agrária colonial e entre proprietários privados. Todavia, ao invés de chegarmos à conclusão de que o processo territorializador conformou e determinou o modo de vida e a perspectiva territorial dos povos indígenas nesse período, que supostamente acataram (ou resistiram) ao modus operandi cartográfico estatal, podemos também entender o contato de forma mais dialógica, considerando a agência e as perspectivas indígenas em seus modos de "captura" dos conhecimentos dos "outros" (VIEIRA, 2010). Nesse sentido o processo territorial do Estado que culmina nas Terras Indígenas caminha pari passo com o exercício da territorialidade indígena, ancorado na sociocosmologia e na política de habitar do povo Potiguara e culminando em dois modos de territorialização, nos quais os indígenas têm de operar na atualidade8.

Segundo Palitot (2005), as bases dos processos de territorialização junto aos Potiguara encontram-se na segunda metade do século XVII, com a constituição dos dois aldeamentos. Na segunda metade do século XVIII, a situação das aldeias missionárias foi modificada pelo diretório pombalino, que determinou a expulsão das ordens missionárias e a elevação das aldeias à categoria de vilas de índios, ampliando os esforços de assimilação dos índios à sociedade colonial e buscando, assim, dissolver as fronteiras sociais entre os aldeados e os demais súditos do rei de Portugal. Processo que, na perspectiva Potiguara, poderia ser descrito de forma inversa, como um modo indígena de assimilar o diferente e inseri-lo em suas redes de parentesco (VIEIRA, 2010), entre outras diversas redes sociais.

Mapas foram usados em momentos cruciais para o país desde o século XIX, como na vinda da família real para o Brasil, em 1808, que é

\footnotetext{
${ }^{8}$ Ver também em outros contextos, Gallois (2004) entre os Wajãpi e Saez (2005) entre os Yaminawa.
} 
vista como um fato marcante na história da mobilização indígena pela garantia do território. No século XVIII, El-rei havia garantido a posse da terra aos índios ao confirmar, por meio da lei, que se doasse a cada missão "uma légua de terra em quadra para a sua sustentação" (DANTAS, SAMPAIO e CARVALHO, 1992 p. 444). Entre vários grupos indígenas do Nordeste brasileiro, a figura de Dom Pedro II é mencionada quando querem atestar o direito ao território onde vivem. No caso dos Potiguara, ele teria doado a área das antigas aldeias de São Miguel de Baía da Traição e da Preguiça (ou Vila de Monte Mór), delimitadas com marcos de pedra dos quais ainda há vestígios.

No pós-Lei de Terras (de 1850), em 1865, o engenheiro Justa Araújo é mandado à Paraíba para demarcar as terras dos Potiguara com base nos tais marcos de pedra estabelecidos na época da doação de terras (PALITOT, 2005). O mapa elaborado nesse trabalho foi, e ainda é, usado pelos Potiguara como uma "prova" de sua presença no norte da Paraíba. Esses mapeamentos não impediram o avanço do capitalismo privado nas terras dos povos indígenas da região, como no caso da instalação da fábrica da Companhia de Tecidos Rio Tinto, cujas narrativas são carregadas de emoção e de lembranças do sofrimento vivido pelas pessoas que viveram tais experiências. Com a chegada do Serviço de Proteção aos Índios (SPI), inicia-se um processo de negação da presença indígena pelo poder tutelar associado ao poder econômico e a subsequente tentativa de apagá-los do mapa.

No final da década de 1980, em cenário político propício e com a forte presença de um movimento indígena vigoroso, processos de demarcação e de autodemarcação das Terras Indígenas emergem, tendo por base a elaboração de outros mapas produzidos pelo exército e pela Funai. Nestes últimos mapas estatais, podemos observar uma redução drástica das dimensões das terras destinadas aos indígenas no século XIX; tais reduções do processo territorializador do Estado Nacional serviram, por outro lado, para orientar as reinvidicações dos movimentos indígenas de retomada de terras, que visam reviver de forma legítima o território subtraído. No caso dos Potiguara, isso se deu através de dois movimentos articulados: o primeiro, baseado no próprio mapa do Estado, com olhar sobre aquele elaborado no período imperial; o segundo, por meio da dinâmica territorial, da geografia vivida e das formas de habitar os 
ambientes, isto é, de criar e manter os lugares outrora vividos, reconhecidos, hoje, como os lugares dos antigos (as taperas velhas), lugares sagrados expressos na genealogia da paisagem (CARDOSO e MODERCIN, 2012).

Os Potiguara tensionam e acomodam de forma ativa e contínua a sua territorialidade, na qual inscrevem o seu modo de mapear o mundo, interagindo, "fagocitando" e protagonizando os processos de territorialização, incluindo aquele direcionado pelo Estado, que caminha ao lado de estratégias cartográficas. O etnomapeamento que aqui relataremos se inscreve nesse contínuo processo de indigenização da cartografia, em consonância com o que vem sendo conhecido como a "virada territorial" (OFTEN, 2009) desse povo. Dessa forma, podemos compreender a relação dos Potiguara com os mapas como a de territorialidades em movimento com um cerne que se revigora, com práticas que se mantêm e que, ao mesmo tempo, incorporam outras estratégias.

\section{Etnografia de um etnomapeamento do território vivido}

Movimentos iniciais:

Em setembro de 2010, chegamos, enquanto consultores contratados pela Funai-Unesco para realizar um Diagnóstico Etnoambiental e Etnomapeamento, pela primeira vez à sede do município de Baía da Traição, uma cidade que cresceu dentro do território indígena. Nos acompanhavam representantes das Coordenações Gerais (CGs), da Coordenação Regional (CR) e das Coordenações Técnicas Locais (CTL) da Funai para apresentar a proposta do estudo às lideranças indígenas locais. Nossas impressões iniciais, comprovadas no decurso do processo, nos levavam a crer que não houve qualquer mobilização concreta, algum trabalho de articulação ou diálogo entre o órgão indigenista e as organizações indígenas, nem entre as Coordenações da Funai em Brasília e as locais de João Pessoa e Baía da Traição; não se explicou do que se tratava a ação que seria desenvolvida. Além disso, o momento foi considerado inadequado do ponto de vista político, com consequências diretas à nossa atuação. Na primeira reunião com as lideranças, 
juntamente com indigenistas da Funai, objetivando apresentar e debater a metodologia a ser utilizada e o cronograma, fomos surpreendidos por um episódio derivado de inúmeras reivindicações dos Potiguara, relacionadas, principalmente, à reestruturação do órgão indigenista.

Para o primeiro encontro, a Funai organizou uma reunião numa pousada da cidade com a finalidade de apresentar a equipe e a iniciativa, bem como seus objetivos, à qual foram convidados caciques e lideranças de praticamente todas, senão todas, as aldeias. Estavam presentes aproximadamente cinquenta pessoas. Três representantes de Coordenações relacionadas a questões de monitoramento territorial, ambiental e etnodesenvolvimento, e uma servidora responsável por acompanhar os trabalhos abriram a conversa com a explicação dos objetivos e a justificativa do estudo proposto para a área.

Em meio a uma das explanações, um cacique se levantou bastante nervoso, questionando a inoperância da Funai desde a mudança da unidade gestora de João Pessoa para Fortaleza, por conta da reestruturação do órgão. O tema motivador era o prejuízo causado à agricultura devido à falta de tratores, já que estes se encontravam quebrados, o que impossibilitou o preparo da terra para o plantio na época adequada. A fala do cacique evidenciou um movimento planejado de reivindicação dos Potiguara perante o governo, ali representado pelos coordenadores e servidores da Funai de Brasília. Assim, o que deveria ser uma reunião de planejamento de oficinas e atividades voltadas para a discussão sobre a gestão ambiental do território tornou-se uma estratégia de pressão sobre o órgão indigenista no atendimento às suas demandas. Almejando conversar diretamente com o presidente da Funai e exigir a revisão da reestruturação da Funai na Paraíba, os Potiguara "recomendaram" que permanecêssemos na aldeia São Francisco até que alguma providência fosse tomada por parte dos técnicos e da presidência da Funai. Sem qualquer ato de violência, algumas lideranças indígenas nos levaram à escola Pedro Poti na aldeia conhecida por "aldeia mãe", onde permanecemos por três dias enquanto aconteciam as negociações entre os indígenas e a Funai. Uma frase recorrente entre os Potiguara era que "esta reunião é uma enrolação!". Não nos alongaremos nas descrições desse evento, embora valha ressaltar que, como todo conflito, isso gerou um aprofundamento das relações e novas possibilidades de trabalho 
conjunto.

Alguns meses após o episódio, nos reunimos novamente com as lideranças e indigenistas da Funai para consultá-los sobre o interesse em dar continuidade ou não aos trabalhos, que objetivava a compreensão das relações que conformam o território e questões voltadas às condições ambientais com a finalidade de melhor orientar futuros projetos. $\mathrm{O}$ tom da conversa foi o de que o etnomapeamento refletiria nos diálogos entre o Estado e povo Potiguara e, portanto, poderia se articular aos interesses dos indígenas. Após a deliberação dos Potiguara em favor à continuidade dos trabalhos, construímos uma agenda conjunta e seguimos para as próximas etapas.

Com os pés no chão:

Solucionados os conflitos que impediram o início do estudo na data prevista, retornamos à área para começar de fato o etnomapeamento através da metodologia proposta, que contemplava basicamente oficinas, entrevistas e caminhadas guiadas, fora o levantamento de dados secundários inerente ao estudo. Previsto para acontecer ao longo de quatro meses, contudo, os percalços no caminho obrigaram a prorrogação para um ano, desde o primeiro encontro até a entrega do diagnóstico etnoambiental e dps etnomapas para a Funai e, posteriormente, para os Potiguara. Consideramos que esse período até foi pouco tempo para mobilizar representantes de uma área com tamanha população e compreender a complexidade das relações sociais e dos ambientes.

Antecedendo a pesquisa de campo propriamente dita, realizamos um primeiro (ou segundo) encontro com as lideranças indígenas e os servidores da Funai para apresentar o estudo e prestar esclarecimentos sobre a nossa compreensão acerca dos conceitos de "etnomapeamento", "território" e "gestão territorial" e planejar conjuntamente a agenda do campo seguinte, quando da realização do etnomapeamento. Esses encontros ocorreram nas escolas das aldeias Jacaré de São Domingos e São Francisco, em que estiveram reunidos representantes de todas as aldeias das TIs envolvidas e funcionários da Funai. Fizemos uma breve apresentação sobre cartografia, explicitamos os objetivos do projeto, 
relatamos experiências semelhantes entre os Pataxó e os Pankararé, esclarecemos a metodologia que pretendíamos utilizar e, por fim, perguntamos sobre o interesse dos presentes em participar das atividades para, em seguida, discutirmos o cronograma e a logística das oficinas. A participação das pessoas foi intensa, revelando-se através de perguntas e comentários sobre os possíveis desdobramentos do trabalho, além de sugestões de temas a serem inseridos no mapeamento. Devido ao grande número de aldeias e ao curto tempo disponível para a execução do estudo, acordamos sobre a formação de dois grupos de trabalho para a realização das oficinas participativas: um com membros das aldeias das TIs Monte Mor e Jacaré São Domingos e outro das aldeias da TI Potiguara.

Desde os primeiros momentos os mapas foram acionados, ou por nós, ou por eles, o que nos levou a constatar a apropriação dos mapas anteriores à ação de mapeamento aqui relatada. Aconteceram novos encontros com os mapas antigos, promovendo outros mapeamentos e um incessante refazer-se dos territórios. Tendo em vista a recepção inicial e as improvisações que nos foram provocadas desde o início, além do interesse manifestado (sobretudo na TI São Francisco, onde, no início, houve pouco interesse, que foi, porém, aumentando com o desdobrar das questões territoriais), seria muita ingenuidade contar com a realização plena do planejamento sem o agenciamento e a condução dos Potiguara.

Entre caminhadas e paragens... no campo:

Com os pés em terras potiguara, iniciamos de fato nosso trabalho - apesar dos feitos anteriores, que nos levaram a vislumbrar superficialmente a complexidade das relações sociais que conformam os territórios superpostos para além da sobreposição estatal entre TIs e UCs. As primeiras ações, seguindo o cronograma construído, envolveram tratar do potencial e das ambiguidades relacionadas ao uso de mapas e imagens de satélite, bem como do georreferenciamento de informações. Consideramos eticamente necessário abordar, mesmo que de forma superficial, esse debate, que sempre custou tão caro aos povos indígenas - mapas moldaram, fragmentaram e reduziram seus territórios materiais. O nosso papel era, então, apontar as possibilidades para conceber os mapas Potiguara e demonstrar os papéis que eles mesmos 
poderiam assumir ao entrar nesse jogo, que reverbera no processo de territorialização. Ao mesmo tempo, nossa atenção se voltava para o mapeamento, que, para além de territórios materiais, transpôs fronteiras e nos levou a territórios amplos e multidimensionais tão complexos quanto as relações e os vínculos que os conformam. Convenhamos que, se considerarmos os primeiros momentos em campo para a execução dessa ação de mapeamento - isto é, a fatídica reunião inicial -, mesmo sem mapas, o mapeamento ocorreu: o território se refazia em seu constante movimento por meio de recursos estratégicos para manter sua integridade.

Enfocamos inicialmente as oficinas de elaboração de mapas e de estudo das imagens de satélite, que envolveram a confecção de mapas desenhados pelos participantes, os quais definiram se partiriam do papel em branco ou de um mapa simples, somente com o contorno dos limites oficiais das Terras Indígenas e dos principais rios. Nesse momento, os movimentos de braços e mãos, empunhados com lápis, canetas e pincéis atômicos, estabeleciam conexões com o papel e com a memória coletivamente compartilhada, num ritmo candente no desenho do lugar vivido (Figura 1 e 2).

Em seguida, após uma breve explicação do funcionamento da captação das imagens de satélite, os participantes realizaram uma observação sistemática da imagem, seguida de narrativas sobre as possíveis causas da configuração atual do mosaico de paisagens e as possibilidades de reversão. Esse momento contribuiu para a localização de atributos importantes para a elaboração de mapas em sistema de informações geográficas (SIG), relevantes para a nossa compreensão das relações territoriais e dos reflexos no ambiente; além disso, proporcionou a discussão sobre a importância ambiental das terras Potiguara neste complexo de áreas protegidas, e, quando houve presença de professores Potiguara no grupo de trabalho, foram apontadas as potencialidades desse tipo de material para uso pedagógico.

Consideramos as oficinas de etnomapeamento como espaços em que diálogos diversos aconteceram. O processo de desenhar se deu simultaneamente; esses desenhos eram conformados por discursos, saberes intergeracionais, discussões, planejamentos e o reconhecimento do território como um todo pelos participantes. A interferência da equipe 
técnica se fez de forma provocativa, com caráter de mediação, em que foram problematizadas questões em torno das formas de uso e ocupação dos ambientes com prioridade à expressão de definições e classificações nativas. Encerramos os trabalhos em grupo com uma pequena oficina voltada para o uso de receptores GPS de navegação.

Figura 1 - Desenho de mapa na aldeia Jacaré de São Domingos

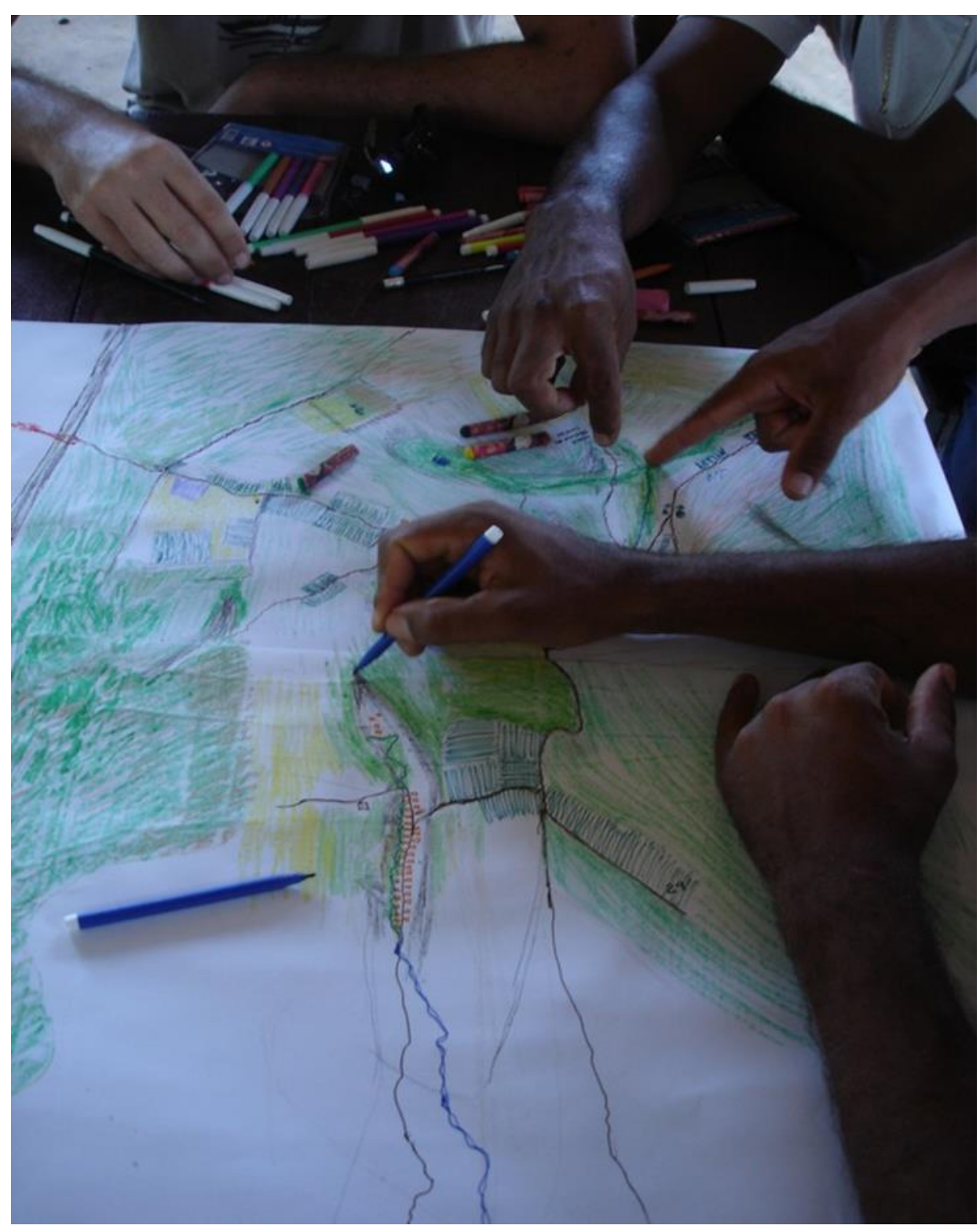

Fonte: Fotografia de Lilian Parra. 
Figura 2 - Grupo de trabalho na aldeia São Francisco.

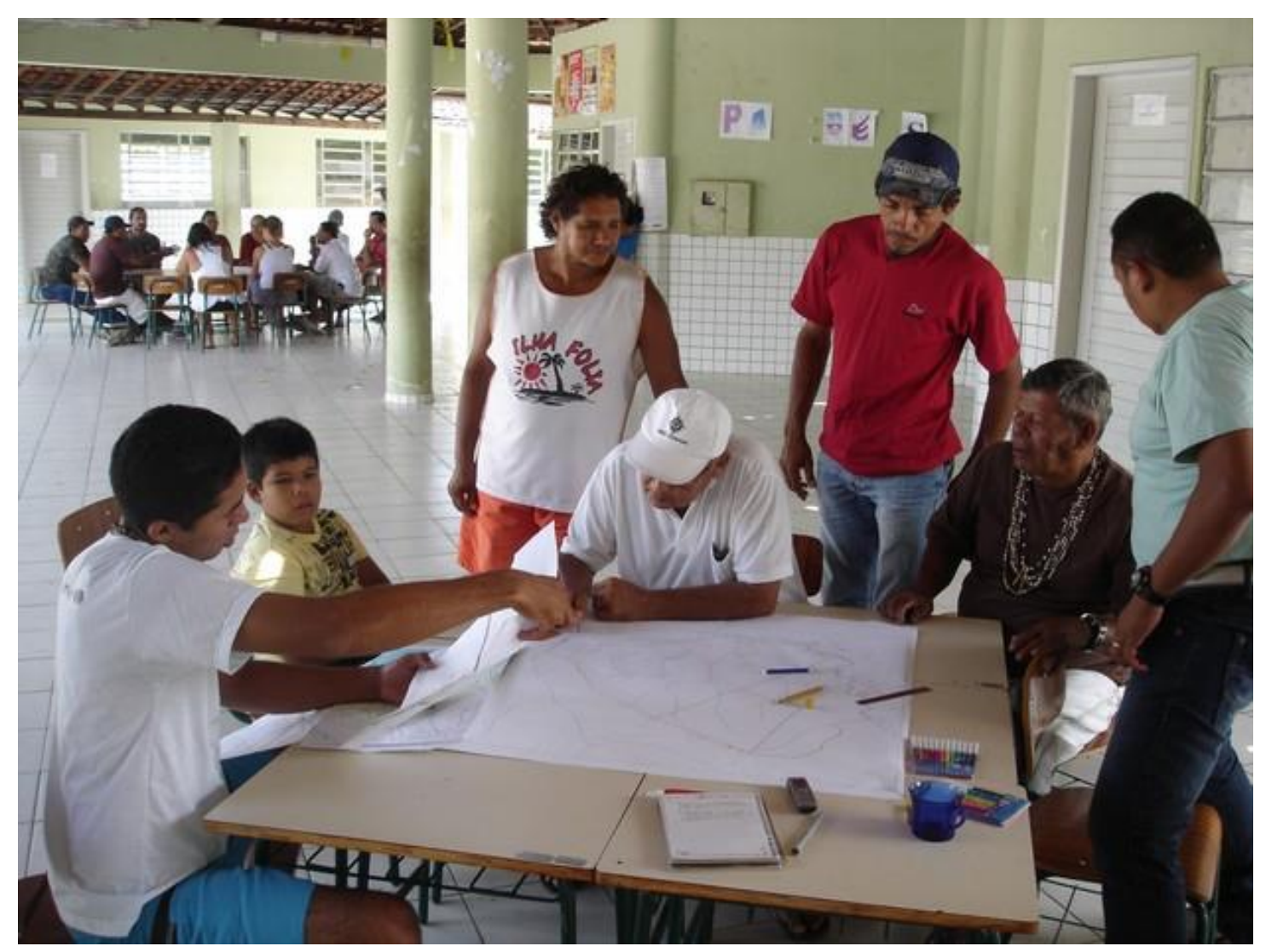

Fonte: Fotografia de Thiago Cardoso.

A dinâmica das oficinas variou de acordo com o número de participantes, o interesse específico dos grupos por determinado tema e, sobretudo, as situações específicas que conduziram à reformulação das estratégias de mapeamento. $\mathrm{O}$ grupo de trabalho inicialmente planejado para reunir representantes das aldeias ${ }^{9}$ das Tls Jacaré de São Domingos e Potiguara de Monte Mór não funcionou devido a conflitos internos em plena tensão e, assim, acabamos por trabalhar com três grupos. A presença expressiva de professores, as questões ambientais e territoriais latentes, o enfoque no potencial pedagógico e a difusão do conhecimento intergeracional, dada a presença de um ancião entre nós, orientaram as discussões, bem como os posteriores percursos guiados pelo território.

Considerando-se a falta de representatividade da TI Jacaré de São Domingos, nos deslocamos, como planejado inicialmente, até a aldeia e

\footnotetext{
${ }^{9}$ Aldeias da TI Monte Mór e Aldeias da TI Jacaré de São Domingos.
} 
agendamos um horário para falar com as lideranças e realizar as atividades, mesmo que com um pequeno grupo - o que de fato ocorreu, e a oficina reuniu apenas cerca de cinco pessoas. As atividades programadas para ocorrer na aldeia São Francisco (TI Potiguara) se deram com grande participação, e consideramos conveniente nos dividirmos em grupos para trabalhar não somente questões relativas à espacialização de fenômenos, mas questões políticas e suas relações com as instituições.

Um dos grupos se concentrou na elaboração dos mapas, e, após tratar brevemente sobre aspectos cartográficos e atributos possíveis de serem incorporados aos etnomapas, partimos para o desenho. Na medida em que se fez necessário, para fins de melhorar a compreensão sobre o processo de mapeamento, bem como contribuir para as discussões sobre planejamento e uso dos recursos naturais existentes no território Potiguara, apresentamos algumas tecnologias existentes, como: as imagens de satélite, as fotografias aéreas e o uso dos receptores do sistema de posicionamento global (GPS), sem deixar de esclarecer que serviriam de base em alguma etapa.

Como resultado dos grupos de trabalho, obtivemos mapas coletivos de cada uma das três TIs. Durante o processo da elaboração dos desenhos, os participantes trataram de questões como o uso dos recursos e gestão territorial, além de discutirem e selecionarem os atributos a serem especializados e realizarem alterações nas toponímias, tendo em vista que alguns dos nomes atuais são resultado de um processo forçado de desterritorialização que ocorreu ao longo da história Potiguara. Remapear esses "lugares" com suas toponímias e histórias fez parte de um processo de reterritorialização material e simbólica por meio do mapa. Tanto na oficina realizada em Monte Mór, quanto em São Francisco, os participantes partiram dos marcos do território para iniciar o mapeamento de elementos importantes. Enquanto desenhistas conduziam o registro, os mais velhos discorriam sobre a história de luta da demarcação e relembravam fatos históricos relacionados aos lugares e às mudanças paisagísticas.

Ao fim de cada oficina, buscamos realizar um planejamento para as expedições pelo território, bem como solicitar a indicação de "conhecedores locais" para nos acompanharem no mapeamento e nas caminhadas guiadas. Conduzidos por esses "conhecedores locais" e com 
os mapas desenhados em mãos (Figura 3), percorremos as três Tls a fim de georreferenciar os elementos representados nos mapas, compreender a nomenclatura, a classificação e os usos locais desses vários elementos: aldeias, lugares específicos, marcos naturais, corpos d'água, estradas, caminhos, ambientes, portos, roças, viveiros, camboas, matas, etc.

Figura 3 - Mapa desenhado do território da Terra Indígena Potiguara

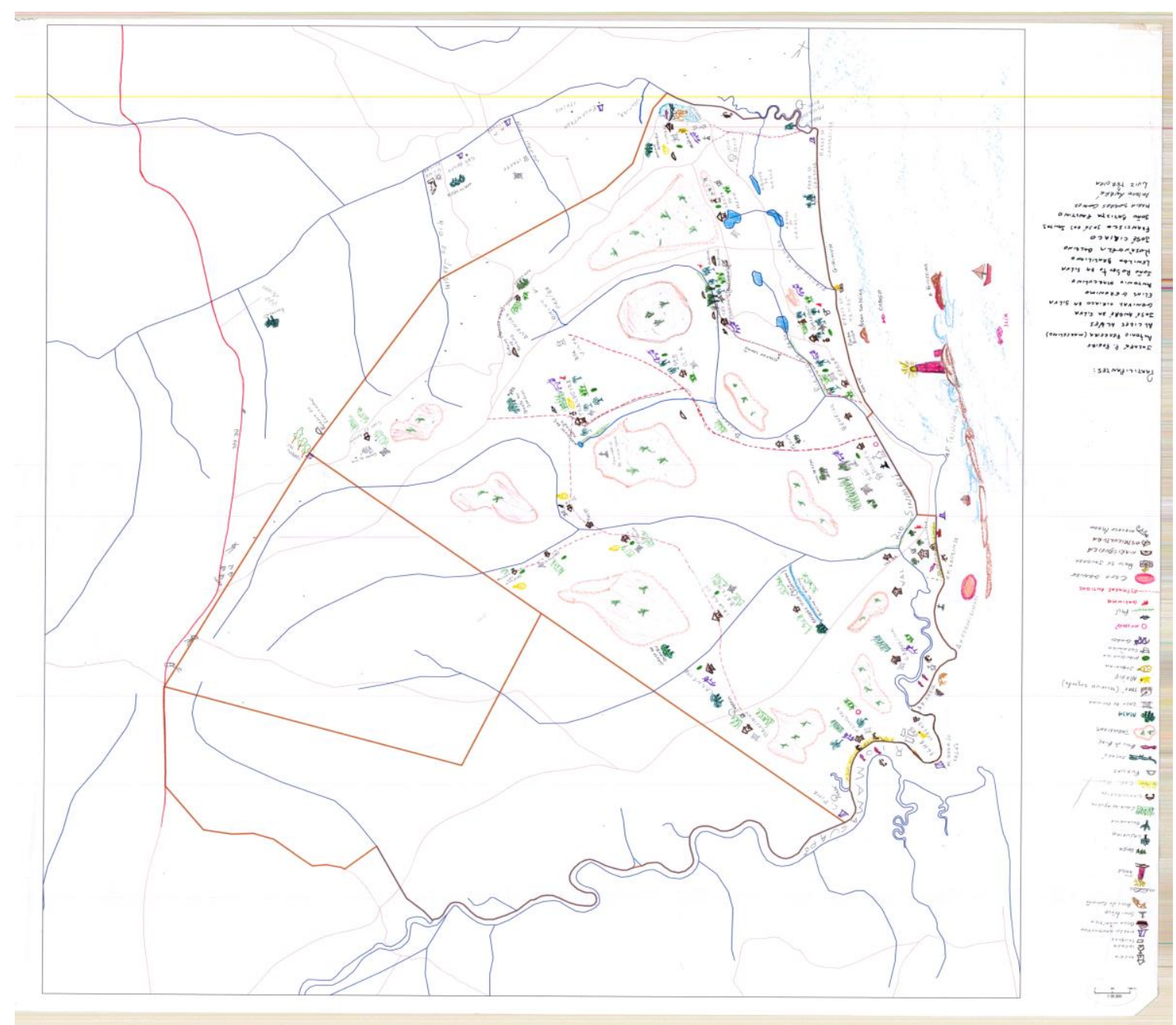

Fonte: Cardoso et al (2012).

As práticas de mapeamento subsequentes àquelas realizadas pelos grupos de trabalho consistiram em realizar caminhadas guiadas com o uso de receptores GPS. Para além da ideia do rigor técnico e da superioridade matemática em relação a outros saberes cartográficos, as caminhadas estão entre as mais importantes práticas de mapear. Como 
bem colocou David Turnbull, "Knowing is a form of travelling, of moving through space; and travelling, like knowledge, is also a form of narrative" (2007, p. 142). Tim Ingold, ao tentar compreender as formas pelas quais as pessoas constróem seus entendimentos nos ambientes através do movimento habilidoso, argumenta que o conhecimento é cultivado pelo movimento ao longo de caminhos que levam ao redor e para longe; que nos conectam a diversos lugares. Ou seja, "we know as we go" (INGOLD, 2000 , p. 229). Portanto, ao caminhar no terreno durante o mapeamento, nos conectamos a lugares e histórias vividas e, a partir daí, dialogamos e experienciamos conhecimentos sobre a paisagem, como narrativas de viagem.

As caminhadas guiadas são imprescindíveis para o reconhecimento de parte do território, pois nela surgem certos tipos de informação que não aparecem nas conversas ou oficinas. Nessas caminhadas guiadas, visitamos algumas roças e canaviais, subimos o rio Mamanguape e descemos o rio Camaratuba de canoa, fomos às nascentes de alguns rios importantes, acompanhamos o trabalho de mariscagem e de farinhada e estivemos em viveiros de camarão e ostra. Além de percorrer o território, conversamos com pessoas, sobretudo no interior das Tls, que nos relataram lembranças referente a determinados locais, o que foi de fundamental importância para a nossa compreensão sobre a história ecológica local.

Após a primeira incursão em campo e o processamento das informações em gabinete, identificamos lacunas e retornamos para caminhar e conversar sobre temas específicos com os Potiguara. Entre estes, destacamos: os conhecimentos sobre a paisagem, o calendário agroextrativista pesqueiro e climático, as cosmologias, o manejo dos recursos naturais, as redes econômicas locais, a disponibilidade de terras para agricultura e as artes de saber-fazer.

\section{Saindo do campo, cessa o movimento?}

Após oficinas e caminhadas, o trabalho com os mapas e dados espaciais passa a ser no gabinete, no "centro de cálculo" (LATOUR e WOOLGAR, 1997) da análise espacial e da confecção de mapas em 
ambiente SIG (Sistemas de Informações Geográficas), que teve início com a transferência dos dados de campo para o banco de dados geográficos. Cabe mencionar que a maioria dos SIGs trabalham sobre dados dotados de referência espacial, em interface gráfica e banco de dados geográficos, estes dotado da capacidade de armazenar dados vetoriais (linhas, pontos, polígonos) e matriciais (imagens, fotos aéreas, modelo digital, entre outros). Não cabe detalhar todas as práticas que concernem à elaboração de mapas neste ambiente; contudo, resumidamente, envolvem: aquisição de dados secundários e primários (incluindo dados de campo, imagens, dados vetoriais, mapas), processamento digital de imagens (georreferenciamento, fusão de bandas, classificação automática, etc.), análise de dados espaciais, vetorização de dados, layout de mapas, entre outros.

A ideia central dos procedimentos dessa fase dos trabalhos é de que os etnomapas poderiam tranquilamente ser transferidos para o formato digital e organizados em um banco de dados - o que não deixa de ser correto se considerarmos que os etnomapas foram construídos sobre mapas de base simples. Contudo, logo no início dessa etapa do mapeamento, nos deparamos com inquietações que se resumem na insatisfação em conceber nossas ricas experiências e vivências junto aos Potiguara como dados passíveis de serem catalogados e classificados. Não podemos esquecer, ainda, que a complexidade inerente à classificação nativa dos ambientes também configurou tema de inúmeras discussões entre os membros da equipe a fim de chegarmos a uma compreensão, mesmo que parcial.

Tais situações ocorreram provavelmente por não termos nos restringido aos atributos registrados nos etnomapas pelos Potiguara, mas nos debruçarmos na compreensão dos ambientes, das estratégias de uso e manejo ambiental e das relações cosmológicas que orientam a gestão dos espaços. Mesclar as informações qualitativas e georreferenciadas, advindas das caminhadas e dos diálogos, com os dados provenientes das imagens de satélites e dos etnomapas configurou, resumidamente, 0 processo de mapeamento em SIG. Nesse momento do trabalho, que foi realizado por nós, consultores, todo o aspecto vivencial, performático, emocional, que tivemos em campo, no ato de mapear, é rasurado para dar lugar a pontos, linhas, polígonos, legendas e cores. 
Nos etnomapas elaborados com aporte de geotecnologias, além dos elementos inseridos no momento da produção dos desenhos, são adicionadas informações georreferenciadas obtidas em caminhadas guiadas pelo território, produtos cartográficos e sensoriamento remoto, reunindo informações de diversas naturezas e gerando novas informações qualitativas e quantitativas, que, ao serem analisadas, permitem elaborar instrumentos de tomada de decisão; dentre eles, os mapas temáticos (CARDOSO et al, 2012). Denominamos estes "etnomapas temáticos" no esforço de diferenciá-los dos etnomapas elaborados pelos Potiguara em campo. Nessa seara, encontramos denominações distintas (croquis, desenhos, esboços, mapas mentais), a fim de não ferir os preceitos básicos do que cartógrafos e demais cientistas consideram por mapa - ou seja, possuir escala e ser dotado de georreferencias expressas pelas coordenadas geodésicas.

Sem desmerecer os esforços daqueles que se dedicam a manter essa suposta integridade, até porque não são poucas as práticas envolvidas para tal, tendemos, porém, a ampliar a referida concepção, haja visto a diversidade de saberes e percepções em torno dos modos de geografar, que vão além dos moldes acadêmicos e científicos. Não vamos nos deter nesse debate a fim de não o reduzir, apesar de ser importante mencioná-lo por fazer parte do processo de reflexão do mapeamento. Resumidamente, não foi tarefa fácil ampliar essa perspectiva, e nem encontrar denominação adequada e didática para explicitar as distinções entre eles: concebemos todos como mapas, processos constituídos por práticas distintas.

Seguimos uma rotina de mapeamento em ambiente SIG, que, no entanto, não é o foco deste espaço. As inquietações permearam todo o processo de mapeamento em SIG, e, entre os aspectos que também configuraram tema polêmico, houve a separação de atributos e características, ou "ambiente de práticas", já que se dão de forma imbricada na concepção Potiguara. Como exigência contratual, a maioria dos etnomapeamentos gera mapas temáticos, separados como se fossem camadas sobrepostas, o que corrobora a lógica dos SIG; neste, não foi diferente. Seja pela familiaridade com que lidamos com as informações dispostas desta maneira, seja pela crença no potencial de combinação e análise desses atributos, ou, ainda, pela facilitação da leitura dos 
fenômenos (uma vez que se acredita que elementos excessivos podem vir a dificultar a leitura dos mapas), cartesianamente, dissociamos os atributos dos ambientes e das práticas Potiguara. Tal feito pode apresentar prós se pensarmos na comunicação cartográfica com parceiros; contudo, a compreensão dos fenômenos é parcial, e não temos ideia dos prejuízos que podem ser ocasionados.

\section{O que narram os mapas}

Apesar de permitirem aferir a distribuição espacial dos fenômenos, mesmo que parcialmente, os mapas, nos termos de Kitchin e Dodge (2007), não passam de tinta no papel se dissociados das práticas que o fazem emergir, aquelas que os tornam mapas, sejam de elaboração ou de usos múltiplos. Ao longo do etnomapeamento, foram de fato diversas, em campo ou em gabinete, com ou sem a presença física dos Potiguara - isso porque foram diversos os momentos com membros deste povo e, portanto, parte do que vivenciamos com eles estava impresso em nós de alguma maneira, interferindo em nossas ações.

Cada mapa tem por trás de si uma série de particularidades. Algumas delas nos ajudam a compreender uma parte do que eles narram, que é o nosso interesse especial nesta seção. Afirmamos, neste caso, que o mapa aqui não é um território, mas um saber, uma verdade, uma percepção sobre o mundo narrada através de "lentes" bidimensionais. Da mescla de práticas de campo associadas aos procedimentos realizados em SIG, resultaram os etnomapas temáticos de ambientes, solos, impactos e conflitos socioambientais, bem como dos usos dos recursos naturais e das redes econômicas. Em programa específico ${ }^{10}$, munidos de imagem de satélite ${ }^{11}$ e dados altimétricos ${ }^{12}$, iniciamos a elaboração de um mapa-base com informações de hidrografia, rede viária, localidade e demais atributos planialtimétricos, de forma a atualizar as cartas topográficas oficiais (IBGE).

\footnotetext{
${ }^{10}$ Arcgis 9.2, versão trial.

${ }^{11}$ Satélite Landsat 7 de 2001, disponibilizada pelo Instituto Nacional de Pesquisas Espaciais( INPE) e imagens atuais e históricas disponibilizadas pelo Google Earth.

12 Dados do Shuttle Radar Topography Mission (SRTM, disponibilizados pela Empresa Brasileira de Pesquisa Agropecuária (Embrapa).
} 
Cardoso, Parra e Mordecin - Mapas em Movimento...

Figura 4 - Mapa de Uso

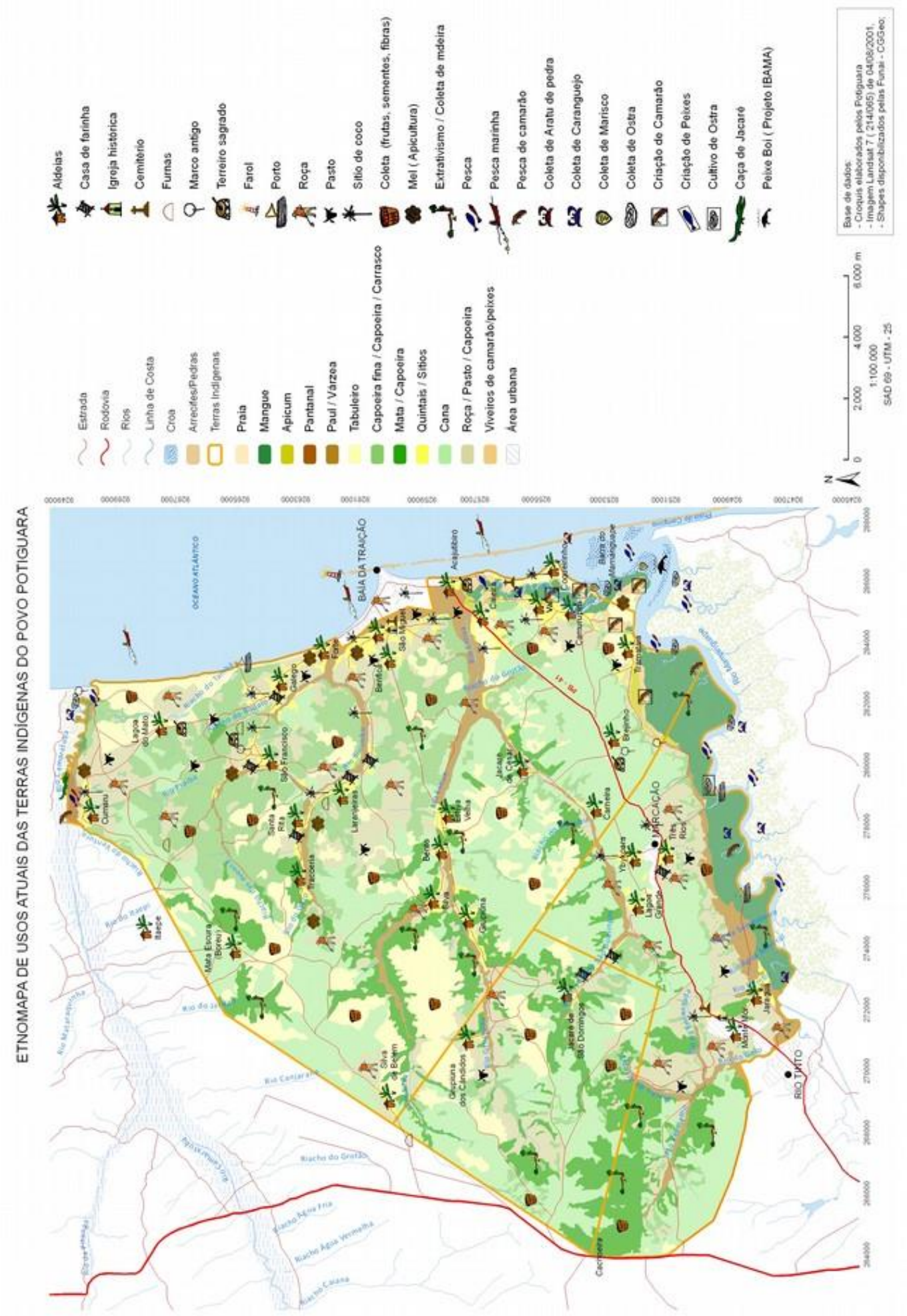

Fonte: Cardoso et al (2012). 
Em seguida, realizamos a vetorização dos ambientes, pautados, principalmente, nas descrições Potiguara, cruzadas com os dados georreferenciados das caminhadas guiadas, entrevistas e características espectrais, sem desconsiderar a escala cartográfica de saída dos mapas (1:40000). Como categorias nativas dos ambientes, tivemos: praia, mangue, apicum, pantanal, paú/várzea, tabuleiro, capoeira fina/capoeira/carrasco, mata/capoeira, quintais/sítios, roça/pasto/capoeira, cana, viveiros de camarão/peixes, área urbana. Preenchidas todas as Tls com áreas relativas aos ambientes, extraímos outras informações relacionadas (Figura 3).

Do mapa de ambientes emerge o mapa de solos, baseado na correlação entre vegetação, aptidão agrícola, relevo e dados qualitativos (descrição dos atributos do solo) registrados em campo ao percorrer o território com os Potiguara. Na caminhada guiada, os especialistas locais se valiam de cortes de estrada para nos explicar a distribuição das camadas e identificar diferenças qualitativas entre os solos. Esse mapa não passou despercebido pelos engenheiros agrônomos, que eventualmente nos acompanharam; não realizamos análise de solo, mas pautamo-nos na classificação, nas percepções e nos conhecimentos dos especialistas e nos indicativos dos Potiguara para elaborá-lo. Estes últimos se valem principalmente de critérios como textura, cor e aptidão para denominação e determinação da abrangência dos solos pelo território. Os tipos de solo captados e passíveis de serem espacializados através desse método são: areia, areia branca, areia preta com barro, areia vermelha com barro, barro, lama e lama com areia. Nos restringimos às camadas superficiais ou a associações pré-estabelecidas. Entre os que não foram espacializados, estão: massamê, massapê, massapê preto, tumbatinga, cabeça de carneira e piçarro.

A fim de reconectar ambientes e práticas, colocamos no mesmo mapa atributos relativos aos ambientes e às práticas que neles ocorrem, dando origem ao denominado "mapa de usos atuais". Totalizam 31 categorias, que, além do uso dos recursos naturais, incluem pontos de referências e locais históricos, rituais e sagrados. Entre elas, temos: pesca marinha, coleta de aratu de pedra, coleta de caranguejo, coleta de mariscos, coleta de ostra, pesca de camarão, criação de camarão, criação de ostra, porto, caça do Jacaré, peixe boi, farol, terreiro sagrado, igreja 
histórica, cemitério, marco antigo, furnas, quintais, casa de farinha, roça, gado, cana, bananeiras, sítio de coco, sítio de caju, mel, coleta (de frutas, sementes e fibras), extrativismo e coleta de madeira e cachoeira. Ao mapa de usos adicionamos informações de projetos que ocorriam na época e de projetos futuros, o que permitiu visualizar a diversidade de atividades e possibilidades econômicas.

Ainda sobre os ambientes, relacionamos impactos e conflitos socioambientais e territoriais, haja visto a intensidade e a frequência com que os diversos impactos e conflitos socioambientais nos foram relatados. Contudo, observamos que existem impactos necessariamente negativos: há tantos problemas como soluções e potencialidades que se expressaram a partir de iniciativas pontuais e que precisam continuamente de força para se manter em territórios com múltiplos interesses. Além da área das terras indígenas, mapeamos locais importantes no entorno, que, sob a ótica Potiguara, causaram impactos diretos, como as usinas, as áreas de monocultivo de cana e a fábrica de baterias.

Durante o estudo, as categorias de conflitos e impactos socioambientais evidenciadas foram: áreas degradadas, contaminação por agrotóxicos, usinas e seus rejeitos, fábrica de baterias e seus rejeitos, voçorocas e ravinas, assoreamento, áreas sujeitas a desmatamento, áreas preservadas, áreas de recuperação, depósitos de lixo, carcinicultura e sobreposição de UC (APA e ARIE). A discussão coletiva sobre esse instrumento pode possibilitar a difusão da discussão sobre os conflitos, que, analisados com olhares diferentes, permitem vislumbrar caminhos para solucioná-los. Consideramos as informações sobre os conflitos e impactos de grande importância para subsidiar discussões e ações futuras no âmbito da gestão ambiental.

Julgamos, naquele momento, ser proveitoso espacializar a diversidade de redes econômicas e fluxos de produtos e serviços que ocorriam nas referidas terras, para contrapor o discurso monotemático da produção de cana e da carcinicultura. As redes econômicas foram desenhadas partindo dos dados de campo, das informações obtidas dos diálogos semiestruturados e das detalhadas informações fornecidas por Luis Pereira (CTL Baía da Traição); foram desenhadas sobre os limites das terras indígenas, relacionando as aldeias entre si e com os centros 
urbanos, onde escoam sua produção e de onde vêm os suplementos necessários.

As redes econômicas e os fluxos de produtos e serviços, incluindo trocas e reciprocidades mapeadas, foram: mandioca (raiz, farinha, beijus e tapiocas), frutas (manga, coco, mangaba, caju/castanha, jaca, mamão, maracujá, abacaxi, banana e acerola), cana-de-açúcar, hortaliças e temperos, leguminosas e milho, pescados, camarão, camarão de viveiro, mel, produtos industrializados, viveiros de camarão (ração e sementes), ciclo da cana (insumos, sementes, tratores e trabalhadores), ciclo da Funai (ferramentas, tratores, sementes, cestas básicas, barco e material para pesca) e pecuária.

Foram dois os mapas gerados com esta temática: o primeiro contém todas as redes econômicas juntas num mesmo mapa, o que torna praticamente impossível a leitura. Nós o consideramos interessante para demonstrar a diversidade de atividades econômicas que ocorrem nas TIs, pois ele permite visualizar a concentração, a distribuição e a diversidade produtiva de cada aldeia, bem como a dependência dos produtos que vêm dos mercados e das feiras das redondezas. O segundo consideramos uma coleção de mapas nessa mesma temática, em que, diferentemente, as redes são apresentadas separadamente, para melhor compreensão de cada.

\section{O retorno dos mapas}

Ao finalizarmos a etapa de elaboração dos mapas, apresentamos os resultados à comunidade em alguns eventos distintos. O primeiro ocorreu durante as atividades festivas em comemoração ao Dia do Índio, em abril de 2012. Nas apresentações de Toré em algumas das aldeias envolvidas, montamos painéis com registros fotográficos ao lado do que chamamos de "varal de mapas", no qual estavam dispostos os etnomapas e os mapas temáticos. Ao lado de cada um, amarramos canetas para que os Potiguara pudessem realizar inserções, correções, comentários - o que bem entendessem. Na medida do possível, realizamos explicações e esclarecimentos de dúvidas acerca dos mapas e do processo como um todo. Esse foi o primeiro passo rumo à difusão do etnomapeamento entre 
os Potiguara e seus parceiros.

Nos meses que seguiram, tivemos outras oportunidades nesse sentido, como a elaboração de um livro intitulado Etnomapeamento Potiguara, publicado pela Funai em 2012, e a participação em um evento destinado à difusão do material aos professores de todas as escolas das TIs. Neste último, plotamos os mapas em lona para deixá-los nas escolas e distribuímos os exemplares do livro. Foi um evento interessante, no qual outras pessoas que não conheciam o trabalho puderem ter acesso a ele, além de obter material validado pelos Potiguara para fins pedagógicos. Ainda no sentido de potencializar a apropriação do etnomapeamento pelos Potiguara, tivemos a oportunidade de participar ao lado destes em um evento destinado ao debate acerca dos mapas e das práticas de mapeamento denominado "Outros mapas".

\section{Desdobramentos, apropriações, reflexões}

Os desdobramentos do etnomapeamento e a forma como os índios Potiguara vêm se apropriando dos etnomapas revelam a importância tanto do processo, quanto do produto. No entanto, cabe destacar que os encaminhamentos só são possíveis devido às relações estabelecidas durante o processo entre a equipe, os técnicos da Funai e as lideranças indígenas. Para se chegar ao que consideramos ser o resultado final material - seis mapas temáticos, acompanhados de um estudo etnoambiental - nos movimentamos em oficinas e caminhadas e, por que não?, em sonhos em noites mal dormidas. Anciões contaram suas histórias de luta e jovens aprenderam sobre usos e apropriações dos recursos ambientais; conflitos e impactos socioambientais foram evidenciados, e suas causas e consequências, refletidas em grupo; ainda, conhecimentos de variadas naturezas entraram em diálogo durante a construção dos mapas. Mal-entendidos e equivocações ocorreram, mas também acordos sobre como e o que mapear.

Tal processo foi promovido quase em sua totalidade pelos técnicos envolvidos em conjunto com um grupo escolhido pelas comunidades indígenas. No entanto, da fase de planejamento até a análise dos dados em SIG, a participação foi majoritariamente nossa, o que, de certa forma, 
contribui para a rasura do protagonismo indígena na totalidade da experiência. O desejável é que o povo indígena, ao ter acesso às geotecnologias, compreenda toda a potencialidade do seu uso, isto é, que tenha a possibilidade de incorporá-las no seu leque de práticas ao longo de todo etnomapeamento. Mesmo não exercendo o papel de "formuladores", os indígenas que participaram do etnomapeamento foram ativos na produção dos mapas: direcionaram as atividades, seu conteúdo e seus usos; redirecionaram sua finalidade e os incorporaram às suas demandas. Observamos, primeiramente, que, assim como outros mapas produzidos na região, o processo do etnomapeamento foi reorientado pelos Potiguara, para fins, principalmente, de luta territorial. Os objetivos planejados pelo órgão indigenista (por exemplo, lidar com conflitos entre órgãos da federação no campo ambiental) foram digeridos, e os mapas, apropriados pelos Potiguara - e não puramente para um diálogo destinado somente à gestão territorial fomentada por agentes externos.

Os mapas estão sendo utilizados como instrumento pedagógico nas escolas e estão relacionados, de certa forma, com atividades de educação ambiental, como iniciativas de reflorestamento de áreas degradadas e elaborações e realizações de outros projetos socioambientais voltados para a gestão territorial. Nesses casos, eles significam uma possibilidade de estreitamento da comunicação entre a gestão indígena e não indígena. Um Potiguara que participou ativamente do processo conta o que um etnomapa pode trazer de novo se já se conhece o território tão bem: "nós já sabemos, mas, com o mapa, é como se tivéssemos tudo na palma da mão". Ele olha para o mapa e rapidamente acessa uma série de informações, mas ele o faz com propriedade, possivelmente porque, além de conhecer o território habitado por sua experiência cotidiana, foi juntamente a outros indígenas, consultores e servidores da Funai que esse mapa foi construído - mesmo que, em algum momento, como na etapa de gabinete, eles não estivessem presentes fisicamente.

Percebemos que aquele que participaram ativamente do etnomapeamento foram os indígenas envolvidos de algum modo com ações de preservação, reflorestamento e busca por alternativas econômicas sustentáveis, como os agricultores tradicionais, pescadores, 
catadores de mangaba e, principalmente, membros das lideranças, como caciques, ex-caciques e pajés, além de professores, agentes de saúde e servidores da Funai indígenas. Essas iniciativas e projetos, segundo aqueles que os coordenam, ganham força e credibilidade com o aporte dos mapas, tanto quando são usados para conscientização, quanto quando são usados para a fortalecer as narrativas e propostas frente aos parceiros. Em termos práticos, os mapas vão anexos a projetos de reflorestamento e preservação das áreas a serem recuperadas e preservadas.

O etnomapeamento foi publicado em livro (CARDOSO et al, 2012), que, além de ser utilizado nas escolas indígenas, tem sido apresentado a diferentes setores de órgãos governamentais como um ilustrativo da argumentação das lideranças. Por exemplo, foi apresentado ao Ministro da Saúde, com destaque para a quantidade de rios que cruzam o território e que estão sendo poluídos pela falta de saneamento básico e pelo uso de produtos químicos nas plantações de cana-de-açúcar. Apesar desses pequenos exemplos, os quais se relacionam diretamente ao etnomapeamento, seja porque o processo de mapear o potencializou, seja porque as pessoas que já estavam envolvidas nessas ações foram as que participaram diretamente do etnomapeamento, não nos sentimos capazes de avaliar ainda o impacto desse trabalho num território tão complexo, com habitantes, ambientes, modos de vida e desejos tão distintos, envolvidos em delicadas relações de poder.

\section{Considerações finais}

Mapas resultam do entrelaçamento cartoprático das múltiplas agencialidades imersas em sua formulação. Ao findar sua confecção, eles não se encerram: continuam vivos, fluindo em diversos contextos e afetando realidades. Ainda há um grande caminho a ser percorrido até que se possa considerar os etnomapas como produtos do conhecimento de uma pluralidade de saberes parciais. Na verdade, é possível que esse caminho não possa nem ser trilhado, haja vista que o etnomapeamento não deixa de ser composto por uma constelação de práticas de mapeamento (CARDOSO, 2014; PARRA, 2016). Ou seja o 
etnomapeamento não deixa de ser, em seu discurso, uma prática multicultural, que permeia um campo situacional de pluralismo e diversidade agonística entre modos de conhecimento.

$\mathrm{O}$ acesso às geotecnologias ainda é restrito aos técnicos e profissionais da cartografia; no entanto, há forte interesse dos Potiguara em se valer dessas técnicas de forma mais autônoma, uma vez que elas subsidiam suas ações. Apesar de não ter sido o objetivo principal da consultoria contratada, os indígenas que se envolveram no projeto valorizaram o método mais do que o esperado e, em certos casos, apropriaram-se de fato dos instrumentos e das técnicas, buscando oportunidades para viabilizar o acesso a tecnologias e capacitações. De certa forma, a proposta do estudo era essa: transpor não um "vazio cartográfico", mas a monotonia das narrativas sobre o conflito e a incapacidade dos Potiguara de relatar e manejar seus ambientes vitais, expressos em cartas cartográficas. Ao olharmos para as práticas Potiguara, nosso objetivo foi, com as técnicas de mapeamento, espacializar a diversidade, mostrar a gama de paisagens e ambientes manejados. Tendo o mapa servido como uma ferramenta de visibilidade, de diálogo e negociação com o entorno e com diversos atores não indígenas, internamente, podemos pensar que o processo possibilitou reflexão e entradas para negociações de visões divergentes dentro do próprio grupo indígena.

Apesar do esforço em transmitir o potencial das técnicas e ferramentas e aprender as categorias nativas, ainda consideramos que a denominação etnomapa como um mapa produzido por determinado grupo étnico é um certo exagero, pois, afinal, a cartografia é a base, e o mapear foi feito com técnicas científicas sem que houvesse tempo ou contexto para aprendermos as formas de mapeamento indígena. Ou seja, o etnomapa trata-se, antes de tudo, de uma incorporação do conteúdo, mas não da forma do conhecimento indígena.

Dessa forma, cabe chamar atenção para os apontamentos que Turnbull (2007) faz ao processo de conexão entre múltiplos conhecimentos indígenas e a tecnociência nos mapeamentos participativos. Turnbull critica a visão, ventilada por boa parte da cartografia técnica, de que indígenas e seus conhecimentos tradicionais, locais ou de base local não são capazes de avaliação racional, de 
unificação e aglutinação. Nesse caso, não poderiam ser transferidos de seu local de produção e realocados em um arquivo central ou banco de dados, não sendo comensuráveis com o conhecimento científico, supostamente de caráter universal, racional, objetivo, passível de ser testado e avaliado.

Por outro lado, o autor expõe aqueles que defendem que o valor do conhecimento indígena reside precisamente em seu caráter local e que é, por conseguinte, necessário descontextualizá-lo para torná-lo comensurável com o conhecimento científico. Nesse sentido, várias versões dessa segunda perspectiva vêm sendo expressas por indígenas e por assessores em mapeamento que utilizam bancos de dados e geotecnologias para obter alguma vantagem em reivindicações de terras tradicionais e manejo de recurso.

Contudo, para Turnbull, ambas as perspectivas suprimem diferentes ontologias e epistemologias. Portanto, o mapeamento e a base de dados com fundamentação técnico-científico, com vistas à comensurabilidade e à universalidade entre conhecimentos, além de subsumir diferentes espacialidades e temporalidades em um espaço abstrato de tempo, também omite a "dimensão multifacetada e interativa dos locais e da prática, as histórias e as viagens e movimentos, e o experiencial" (2007, p. 141). O que nos leva por um caminho da relacionalidade, ao apontarmos o caráter processual dos mapeamentos, à ênfase na multiplicidade de formas, como um ponto de partida para os desafios amplos que os etnógrafos e cartógrafos que simpatizam com tais práticas encontrarão em seus itinerários cartopráticos.

Os etnomapas não devem ser meras reproduções de mapas realizados por instituições públicas, com categorias técnicas, mas sim expressões do pensamento indígena sobre o espaço, reunidas num instrumento cartográfico. Aqui reside outro fator limitador dos mapas produzidos na experiência relatada: será que os mapas, que são formas bidimensionais de ler a paisagem, típicas do pensamento ocidental, podem expressar o conhecimento indígena, que muitas vezes possui leitura tridimensional ou multidimensional da geografia, até mais vívida, dinâmica e historicizada do que os mapas estáticos da cartografia? Não seria, na verdade, um instrumento que fragmenta e reduz este saber, aglutinando-o à matriz do pensamento naturalista? 
Para Cardoso (2014, p. 21), a produção de mapas e o uso de geotecnologias da ciência cartográfica nos fez varrer para o canto de nossos olhos e ouvidos toda a subjetividade e emotividade de um mapa vivencial, expressão mesma do engajamento no ambiente, do sentir o aroma no ar, da socialidade entre humanos e não humanos, do evento histórico, da experiência sensitiva e emotiva, dos obstáculos postos e sobrepostos nas rotas e caminhos e do clima que nos envolveu e nos perpassou. Uma varredura que se constitui como um ato de poder, que se estabelece mesmo num diálogo franco, sensível e dialógico - mesmo numa cartografia compartilhada e participativa.

Portanto, como Ingold (2000) vem colocando, a produção de mapas pode extrair a vida mesma, como expressa nas narrativas e no cotidiano vivido dos povos indígenas. Para este autor, no mundo cartográfico, tudo está parado e silencioso, não existe nem a luz do sol, nem da lua; não existe nenhuma variação de luz ou tonalidade, não há nuvens, não há sombras e não há reflexões. O vento não sopra, deixando as árvores quietas e as águas sem ondas. Nenhum pássaro voa no céu, ou canta na mata; florestas e pastagens são privadas de animais; casas e ruas são vazias de pessoas e trânsito. Rejeitar tudo isso - sugerir que o que é excluído na redução cartográfica equivale, nas palavras de Monmonier, a uma "neblina de detalhe" - é perverso, para dizer o mínimo (WOOD, 1992, p. 76). Pois, não é nada menos que a própria vida. (INGOLD, 2000, p. 242).

Portanto, nós, praticantes das denominadas etnocartografias, devemos nos atentar (o que se configura como um desafio) para a perversão de excluir do cenário e "jogar para baixo do tapete" toda forma de vida e de movimento inerente ao nosso próprio ato de mapear junto a nossos colegas interlocutores, observando, como contraposição a esse fator limitador dos mapas, todas as potência e possibilidades multitécnicas do ato de mapear. Nos termos de Santos (2003), trata-se de "politizar as novas tecnologias" (não tão novas no caso das etnocartográfias), de trazer à tona suas relações com o poder e a ciência ao invés de deixá-las no âmbito das políticas tecnológicas dos Estados e das empresas transnacionais. Ou seja, opções tecnológicas nos remetem para além da apropriação: são questões sociotécnicas.

Apesar de concordarmos que os etnomapas e as geotecnologias 
por trás de sua elaboração, mesmo que redigidos no formato da cartografia técnica extremamente complexa, possuem importância política para a gestão territorial indígena, tivemos uma abordagem autocrítica. Acreditamos que, em paralelo aos "mapas mentais" e ao SIG, podem ser testadas outras formas de realizar um etnomapeamento, sem que se abandone a cartografia, que não sejam tão endereçadas ao conhecimento ecogeográfico indígena. Uma delas seria o "retorno" à elaboração das maquetes ou à própria narração das vivências nos espaços, transformadas em vídeos e desenhos através das chamadas hipermídias (DEVOS, SOARES e ROCHA, 2010). Como já dito, esse exemplo não exclui os mapas planos (bidimensionais) e os SIGs, pois são justamente essas ferramentas, situadas de forma privilegiadas no campo de ação dos Estados nacionais, aquelas pelas quais os povos indígenas dialogam ou lutam por seus direitos e pela sustentação de seus territórios. Defendemos, caso seja entendida como necessária pelos grupos sociais, uma real compreensão e apropriação da cartografia como recurso para a garantia dos direitos, como instrumento de luta. Para isso, é necessário que ocorra uma formação cartográfica crítica, que transcenda o campo da compreensão das projeções, coordenadas e escalas dos mapas e vá a fundo nas potencialidades dos mapas, na história de uso dos mapas em territórios indígenas. Esta deve, ainda, ser colocada em tensão com outras formas de mapear.

O etnomapeamento, com todos os seus limites e riscos já explicitados acima, constituiu-se, na experiência aqui relatada, como uma constelação de práticas interessante e útil para lidar com questões ligadas ao território e à vida dos Potiguara. Durante o processo de etnomapeamento, houve um movimento de "apropriação" ou "indigenização da cartografia" e uma mudança na trajetória dos objetivos e dos usos dos etnomapas. Se, por parte do Estado, eles deveriam orientar a gestão ambiental e apoiar a mitigação de conflitos, os indígenas, por sua vez, se orientam e se motivam por demandas diversas ligadas à luta territorial. negando o "mito do funil demarcatório"13. Portanto, o processo bem como os mapas propriamente ditos, possui caráter político para os

\footnotetext{
${ }^{13}$ Supõem-se, no âmbito de parte do indigenismo oficial, que a tarefa de demarcação de territórios indígenas estaria por se completar, cabendo ao governo cada vez mais apoiar a gestão dos territórios, uma vez que cada vez menos teriam de atender a demandas por territórios. Tal afirmação não condiz com a proliferação de demandas para reconhecimento étnico e territorial.
} 
Potiguara, implicando na busca pelo respeito e pela simetria nas relações, bem como na conquista e na sustentabilidade de seus territórios.

\section{Referências bibliográficas}

ACSELRAD, Henry; COLI, L. R. Disputas territoriais e disputas cartográficas. In: ASCELRAD, H. (Org.). Cartografias sociais e territórios. Rio de Janeiro: IPPUR/UFRJ, 2008. p. 13-44.

ALMEIDA, Mauro William Barbosa. Outros mapas. Conferência de Encerramento do Seminário Outros Mapas: Cartografia e Pesquisa Social. Recife, Fundação Joaquim Nabuco, 2012. Disponível em: https://mwba.files.wordpress.com/2010/06/almeida2012-outros-mapas-cartografia.pdf. Acesso em: 28 maio 2017.

AZEVEDO, Ana Lucia Lobato. A Terra somo nossa: uma análise de processos políticos na construção da terra Potiguara.1986. 258 f. Dissertação (Mestrado em Antropologia Social) - Rio de Janeiro, Universidade Federal do Rio de Janeiro, [1986].

BARRETO-FILHO, Henyo; CORREIA, Cloude. Gestão ambiental e/ou territorial de/em terras indígenas: subsídios para a construção da Política Nacional de Gestão Ambiental em Terras Indígenas. Brasília: MMA e FUNAI, 2009.

BRASIL. Decreto Federal $n^{0}$ 7.747, de 5 de julho de 2012. Institui a Política Nacional de Gestão Territorial e Ambiental de Terras Indígenas - PNGATI, e dá outras providências. Brasília, 2012.

CARDOSO, Thiago Mota. Malhas territoriais: técnicas, conhecimentos e cosmopolítica do ato de mapear territórios indígenas. Anais da IV Reunião de Antropologia da Ciência e da Técnica (REACT), Campinas, 2014. Disponível em: https://ocs.ige.unicamp.br/ojs/react/article/view/1219. Acesso em: 18 maio 2017.

CARDOSO, Thiago Mota et al. (Org.). Etnomapeamento dos Potiguara da Paraíba. Brasília: FUNAI-DEDOC, 2012.

CARDOSO, Thiago Mota; MODERCIN, Isabel. A construção da paisagem pelos Potiguara: do habitar cotidiano à ecologia política. São Paulo: 28 Reunião Brasileira de Antropologia, 2012.

CORREIA, Cloude. Etnozoneamento, etnomapeamento e diagnóstico etnoambiental: representações cartográficas e gestão territorial em terras indígenas no Estado do Acre. 2007. 431 f. Tese (Doutorado em Antropologia) - Brasília: Universidade de Brasília, [2007].

DANTAS, Beatriz; SAMPAIO, José Augusto; CARVALHO, Maria Rosário. Os Povos 
Indígenas no Nordeste Brasileiro: um esboço histórico. In: CARNEIRO DA CUNHA, M. (Org.). História dos Índios no Brasil. São Paulo: FAPESP/SMC/Companhia das Letras, 1992. p. 431-456.

DEL CASINO, Vicent. J.; HANNA, Stephen P. Beyond the "binaries": a methodological intervention for interrogating maps as representational practices. ACME: an international e-journal for critical geographies, v. 4, n. 1, p. 34-56, 2005.

DEVOS, Rafael; SOARES, Ana Paula; ROCHA, Ana Luisa Carvalho. "Habitantes do Arroio": memória ambiental das águas urbanas. Desenvolvimento e Meio Ambiente, Curitiba, n. 22, p. 51-64, 2010.

GALLOIS, Dominique. Terras ocupadas? Territórios? Territorialidades? In: RICARDO, F. (Org.). Terras Indígenas e Unidades de Conservação da Natureza: o desafio das sobreposições territoriais. São Paulo: Instituto Socioambiental, 2004. p. 37-41.

GAVAZZI, Renato Antônio. Planos de Gestão Territorial e Ambiental em Terras Indígenas no Acre. Rio Branco: Papo do Índio, 2008.

HAESBAERT, Rogério. O mito da desterritorialização: do "fim dos territórios" à multi-territorialidade. Rio de Janeiro: Bertrand Brasil, 2004.

HIERRO, Pedro. El enfoque territorial para la gobernanza de los pueblos indigenas amazonicos: limites e possibilidades. IWGIA, Assuntos Indigenas, v. 4, n. 4, 2004.

KITCHIN, Rob; DODGE, Martin. Rethinking maps. Progress in Human Geography, v. 31, n. 3, 2007.

INGOLD, Tim. Perception of the environment: essays livelihood, dwelling and skill. Londres: Routledge, 2000.

2005 .

Towards a politics of dwelling. Conservation and Society, v. 3, p. 501-508,

LATOUR, Bruno; WOOLGAR, Steve. A vida de laboratório: a produção dos fatos científicos. Rio de Janeiro: Relume Dumará, 1997.

LIEDKE, Alice. R. De caboclos urbanos a indígenas rurais: território e etnicidade Potiguara - Aldeia Três Rios, Paraíba, Brasil. Reunião de Antropologia do Mercosul, 2009.

LITTLE, Paul. Gestão territorial em terras indígenas: definição de conceitos e propostas de diretrizes. Rio Branco: Relatório Final, SEMA/SEPI/GTZ, 2006.

MILLER, Robert. P. Análise e Sistematização dos Documentos de Referência sobre Projetos e Políticas Públicas com Interface Direta e Indireta com Gestão e Conservação da Biodiversidade das Terras Indígenas. Brasília: Relatório de Consultoria, TNC, 2008. 
OFFEN, Karl. O mapeas o te mapean: mapeo indígena y negro em América Latina. Tabula rasa, Bogotá, n. 10, p. 163-169, 2009.

PAlitot, Estevão. M. Os Potiguara da Baía da Traição e Monte Mór: história, etnicidade e cultura. 2005. 133 f. Dissertação (Mestrado em Sociologia) - Campina Grande, Universidade Federal de Campina Grande, [2005].

PARRA, Lilian B. Práticas de mapeamento e territorialidades indígenas: uma experiência com os Pataxó do Monte Pascoal. 2016. Dissertação (Mestrado em Geografia) - Florianópolis, Universidade Federal de Santa Catarina, [2016].

PERES, Sidnei. Os Potiguara de Monte-Mor e a luta pelo reconhecimento de seu território. In: RICARDO, Carlos Alberto (Org.). Povos indígenas no Brasil: 1996-2000. São Paulo: Instituto Socioambiental, 2000. p. 543-545.

POSTIGO, Augusto. A terra vista do alto: usos e percepções acerca do espaço entre os moradores do Rio Bagé, Acre. 2010. 310 f. Tese (Doutorado em Antropologia Social) Campinas, Universidade Estadual de Campinas, [2010].

SAEZ, Oscar. C. Kin Paths in an Alien World: Yaminawa Territory and Society. In: SURRALES, Alexandre; HIERRO, Pedro. G. (Org.). The Land Within: Indigenous Territory and Perception of the Environment. Copenhagen: IWGIA, 2005.

SANTOS, Laymert Garcia. Politizar as novas tecnologias: o impacto sócio-técnico da informação digital e genética. São Paulo: Editora 34, 2003.

SEEGERS, A.; CASTRO, V. Terras e territórios indígenas no Brasil. In: SILVEIRA, E. (Org.). Encontros coma civilização brasileira. [S.1.]: [s.n.], 1978. p. 101-108.

Terras e territórios indígenas. Rio de Janeiro: Civilização Brasileira, 1979.

SILVA, Maria da Salete Horácio. Resistência indígena Potiguara: o caso de Jacaré de São Domingos. 1993. 85 f. Dissertação (Mestrado em Serviço Social) - João Pessoa, Universidade Federal da Paraíba, [1993].

SLETTO, Bjorn I. "We drew what we imagined": participatory mapping, performance, and the arts of landscape making. Current Anthropology, v. 50, n. 4, 2009.

SMITH, Maira; GUIMARÃES, Marco Aurélio. Gestão ambiental e territorial de Terras Indígenas: reflexões sobre a construção de uma nova política indigenista. Florianópolis: Anais do Encontro da Associação de Pesquisa e Pós-Graduação em Ambiente e Sociedade, 2010.

SURRALLÉS, Alexandre; GARCÍA HIERRO, Pedro. (Org.). The land within: indigenous territory and perception of the environment. Copenhagen: IWGIA (International Work Group for Indigenous Affairs), 2005. 
TRANCOSO, Ralph et al. EtnoSIG: ferramentas para gestão territorial e ambiental de terras indígenas. In: PAESE, A. et al. (Org.). Conservação da Biodiversidade com SIG. São Paulo: Oficina de Textos, 2012.

TURNBULL, David. Masons, tricksters and cartographers: comparative studies in the sociology of scientific and indigenous knowledge. New York: Routledge, 2003.

Maps narratives and trails: performativity, hodology and distributed knowledges in complex adaptative systems - an approach to emergent mapping. Geographical Research, v.45, n. 2, 2007.

VERDUM, Ricardo. A Gestão Ambiental e Territorial no Brasil Indígena: conceitos, estratégias e mecanismos de apoio no âmbito do MMA/SDS/DADS. Brasília: 2006.

VIEIRA, José Glebson. Amigos e competidores: política faccional e feitiçaria nos Potiguara da Paraíba. 2010. 327 f. Tese (Doutorado em Antropologia) - São Paulo, Universidade de São Paulo, [2010].

VIEIRA, José Glebson; AMOROSO, Marta; VIEGAS, Susana. Dossiê: Transformações das Territorialidades Ameríndias nas Terras Baixas (Brasil). Revista de Antropologia da USP, v. 58, n. 1, 2015.

WOOD, Denis. The Anthropology of cartography. In: ROBERTS, L. (Org.). Mapping culture: place, practice, performance. New York: Palgrave MacMillam, 2012. p. 280303.

Recebido em: 18/06/2017 * Aprovado em: 20/11/2017 * Publicado em: 31/12/2017 